\title{
Concepções de "Humanização" na Ótica de Estudantes de Psicologia / Campus Baixada Santista - Unifesp
}

\author{
Cruz, Carolina de Oliveira; Ba, Sylvia Helena Souza da Silva \\ Unifesp - Universidade Federal de São Paulo - caru.pepm@yahoo.com.br
}

INTRODUÇÃO:a saúde é um fenômeno que intervém na forma como o homem vive; é como cada sujeito constrói um significado para sua vida. Portanto, saber cuidar da pessoa e não só da doença é crucial. a política de humanização do SUS baseia-se no pressuposto da produção de sujeitos autônomos e socialmente responsáveis. Objetivos: Apreender as concepções de discentes sobre humanização; apreender e caracterizar experiências de relato/atendimento que os estudantes reconheçam como exemplo de humanização na saúde; identificar e caracterizar situações de aprendizagem vivenciadas durante o curso de Psicologia que os estudantes destacam em relação à temática "humanização". Métodos: abordagem qualitativa de pesquisa, com o uso do grupo focal com cada uma das 5 turmas de psicologia e, para análise dos dados, a técnica de análise de conteúdo do tipo temática. resultados: em todos os grupos focais emergiu humanização como prática sensível abrangendo olhar integral, promover bem estar a partir de novos modos de pensar e intervir, escuta e possibilidade de colocar-se no lugar do outro, construindo relações democráticas. Conclusões: Os estudantes participantes da pesquisa expressaram o entendimento de que as experiêncais construídas no Eixo Trabalho em Saúde, articulando com as discussões no eixo o Ser Humano e sua Inserção Social e alguns módulos especificos do curso de psicologia, ,incluindo as vivências no Laboratório de Sensibilidades, possibilitaram compreender huamnização como processo que influencia na produção de saúde de homens e mulheres, sujeitos historicamente situados e que são transformados e transformadores de si , de outros e do proprio cotidiano.

Cruz, Carolina de Oliveira; Ba, Sylvia Helena Souza da Silva. Concepções de "Humanização" na Ótica de Estudantes de Psicologia / Campus Baixada Santista - Unifesp. In: Anais do Congresso Internacional de Humanidades \& Humanização em Saúde [= Blucher Medical Proceedings, num.2, vol.1]. São Paulo: Editora Blucher, 2014. ISSN 2357-7282

DOI 10.5151/medpro-cihhs-10528 